\title{
Does Glucose-6-Phosphate Dehydrogenase Deficiency Modify the course of Leprosy or its Treatment
}

J. H. S. PETTIT, M.D., M.R.C.P.

The Research Unit, Sungei Buloh Leprosarium, Selangor, Malaysia, and National Institute for Medical Research, Mill Hill, I.ondon, N.W. 7, England and JAMES CHIN, M.D., M.P.H.

Institute for Medical Research, Kuala I.umpur, Malaysia, and the Hooper Foundation, University of California, San Francisco 22, California, USA

In the past few years there has been an increased interest in the study of the genetics of leprosy (SPICKETT ig62 (a) and (b), BEIGUELMAN I962, HSUEN et al I 963); papers have also been published concerning haemolysis in people under treatment with sulphones (PENGELly ig63). There is, however, a very sparse literature to date about cases of leprosy with glucose-6-phosphate dehydrogenase (G6PD) deficiency (GILles et al, i 96o, GILLES and TAYLOR I 96I) and to the best of our knowledge there is no authoritative paper about the possible modifications that such a deficiency might have on the clinical course of leprosy or its treatment with sulphone.

G6PD deficiency of the erythrocyte is a sex-linked trait that predisposes to haemolytic anaemia from Vicia faba beans (szeinBerg et al i 958) drugs including sulphones, (GILles et al I960, BEUTLER I959) and infections (MARKS I960); and many questions can be raised that have not as yet been fully answered. Do patients, with G6PD deficiency, always develop a haemolytic anaemia when on sulphone therapy? Does this mean that people with leprosy and such a deficiency will respond less well to treatment? Does this mean they will have less erythema nodosum leprosum? These and other questions come rapidly to mind.

\section{METHODS AND PROCEDURES}

A genetic survey of I,073 male patients in Sungei Buloh Leprosarium has recently been made. About 80 per cent of these patients were Chinese, the rest being mainly Malays and Tamils. Among the genetic parameters studied were $\mathrm{ABO}$ and $\mathrm{MN}$ blood groups, secretor factor, phenylthiocarbamide ( $\mathrm{P}^{\prime}$ TC) taste thresholds, colour vision and the G6PD deficiency trait. Abnormal haemoglobins, haptoglobins, and transferrins were studied in a sub-sample of the group. Detailed analysis of these studies will be reported later. Forty-seven patients from the main group were found to have G6PD deficiency and it was thought to be of interest to study whether or not such patients differed in any way, either clinically or in 
response to treatment, from their fellows. Control patients were chosen very carefully from patients of the same racial background (they were not simply matched as 'Chinese' but with others of similar language and (thnic origin, e.g. Hokkien, Hakka, 'Tiechicu etc.) and they were also matched as far as possible according to age and type of leprosy. Of the 47 cases in the study, 42 had two matched controls, two had a single control and for the other three no satisfactorily matching partners could be found in the survey population. All patients were screened for the G6PI) deficiency trait by the rapid dye test of MOTULSKY and CAMPBELL (MOTULsky I960) and those who showed a decolorization time of more than go minutes, were re-tested by this method and also with the Methacmoglobin Reduction test of BREWER et al (I962). A patient was not considered G6PI) deficient unless he was positive to all three tests. Routine micro-hacmatocrit readings were done on all patients. In order to prevent bias in the clinical evaluation, a list of the G6PI) deficient patients and matched controls was drawn up by one of us (Jc) and presented to the other in a random order, and details of all laboratory results were withheld from the clinical investigator until the end of the study. All patients in the original group were scen and diagnosed in the range of TT-BT-BBBI.-I.I. according to the research classification of RIDLEY and JOPLING (I 962) and the following clinical studies were made on each of the selected cases.

First an attempt was made to discover whether or not response to treatment had been quicker or slower than average. This seems to be an extremely difficult decision to make but as most patients had been under treatment for a considerable length of time it was decided that if, in the lepromatous ( $\mathrm{LL}$ ) cases, the smears had become negative in between six to eight years, this would be considered average improvement for our community. If the smears became negative earlier than this they were marked as $+\mathrm{I}$ and if they became negative very quickly (less than three years) they were given a score of +2 . Cases whose bacteria had not disappeared in eight years were marked as - I and those who had no diminution of the smear count in six to eight years or more were marked as -2. A similar assessment was made in borderline lepromatous (BL) cases with adjustment for the fact that the bacterial load at the beginning of treatment would necessarily be lower and so would be associated with more rapid appearance of smear negativity. In tuberculoid cases assessment could not of course be based on smears but had to be made by a clinical impression of the condition over a period of at least two to three years. Although this secms to be difficult, in practice it proved fairly easy to make a satisfactory assessment.

In an attempt to assess whether or not any severe haemolytic condition had occurred in the past, each patient was asked during the investigation whether he had noticed, at any time in his medical history, that his urine was red. Patients were also asked whether or not they 'had had a reaction'. Most of the patients had been in the leprosarium for several years and knew what 'a reaction' was. No attempt was made to differentiate 
erythema nodosum leprosum from the other forms of lepra reaction that are seen in the leprosarium and a simple score was given as follows:

$o$ if the patient had had no reaction of any sort at any time;

I if they had had a reaction which was severe cnough to warrant treatment but not severe enough to need admission to the hospital section of the leprosarium;

2 if the reaction had caused hospitalisation.

\section{Haematocrit readings}

F I N D I N G S

Chart I shows a comparison between the hacmatocrit readings in enzyme deficient cases and in controls and includes only the 42 cases who had a pair of controls. 'I'he average haematocrit readings for the two groups were 39.3 per cent (SI) 4.5) and 40.3 per cent (SI) 4.9) respectively (hardly a significant difference), but the charts themselves, grouping patients in blocks of 5 per cent, secm to show a more clearly observable difference. It is interesting to note that the only patient who had a very low haematocrit was one of the controls whose reading was 16.2 per cent and on further investigation it proved that this was a simple iron-deficient anaemia. There seems to be therefore slight evidence that patients with leprosy who also have G6PD deficiency may have a small reduction in the hacmatocrit reading.

\section{Clinical assessments}

Forty-six patients with G6PD deficiency were seen for clinical assessment, but one had been on treatment for too short a time to decide his rate of improvement. Of the 45 cases assessed six were marked as + I, six as $-\mathrm{I}$, one as -2 and thirty-two as o, making a total assessment change of -2 points in 45 patients. In the control group, clinical assessments of 72 cases were attempted. This is a smaller number than that reported in the haematocrit series because between that investigation and further assessment, a number of patients had left the leprosarium. Of the 72 cases 5 had received too little treatment to assess change. One was marked as -2 , 9 were marked as - I, 49 as o and eight as + I, giving a total change of -3 in 67 cases. Chart II shows that there is no indication that G6PD deficiency modifies the overall response to leprosy treatment.

\section{Haemoglobinuria}

Forty-five G6PD deficient cases were asked whether they had ever noticed a red or very dark urine; one case admitted to having it before the start of sulphone therapy. As far as the control cases were concerned, of the 69 cases questioned three patients stated they noted 'blood in the urine' before they developed leprosy. No patients in either group gave a history suggestive of haemoglobinuria since the start of anti-leprosy treatment and checking of the hospital records confirmed that nobody in these series had been treated for such a complaint. 
Enzyme Deficient Cases

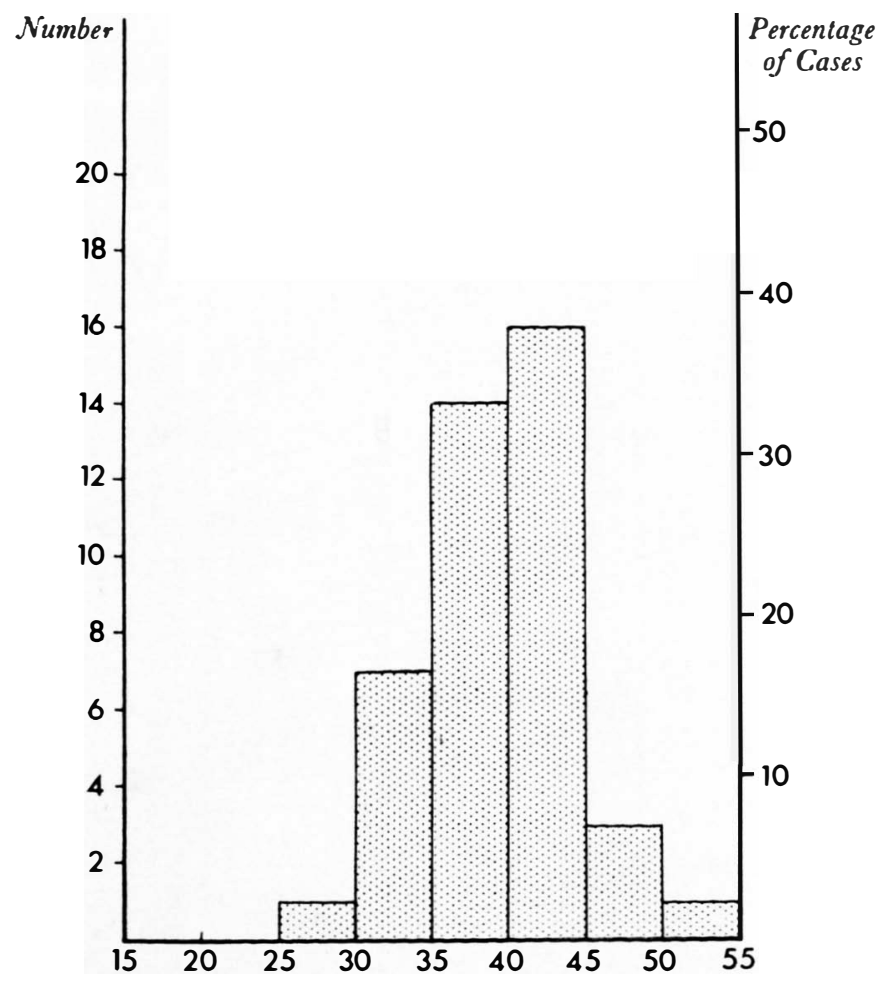

Percentage Haematocrit Readings for 42 cases Average $39 \cdot 3$ per cent (SD $4 \cdot 5$ )
CHART ONE

\section{Control Cases}

Number

Percentage

of Cases

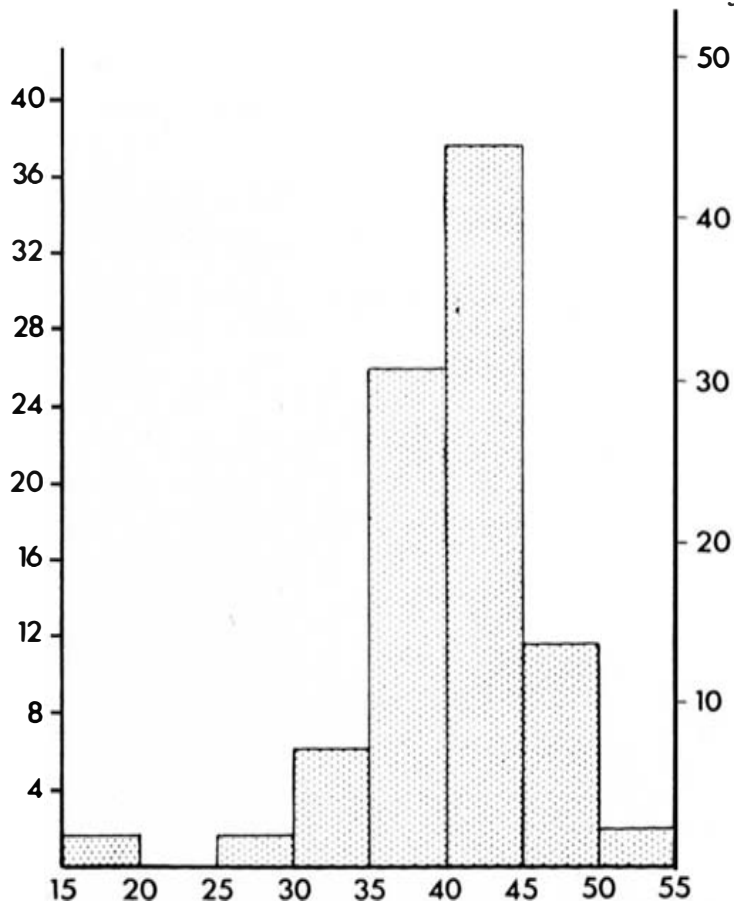

50

40

30

20

10

Percentage Haematocrit Readings for 84 cases Average 40.3 per cent (SD 4.9) 


\section{Reactions}

The method of scoring the reactions has been described above and the results are summarised in Chart III. 'Thirty-one out of the 46 G6PD deficient cases $(67$ per cent) had reactions at some time in the course of their treatment, and 22 of these ( 48 per cent) had required inpatient treatment; among the controls 4 I cases out of 68 (6o per cent) had reacted, 25 of them ( 37 per cent) badly enough to have been admitted. This seems to indicate a higher tendency to react among the G6PD deficient cases but in case the results had been modified by lack of complete pairs of controls further analysis was made on the 30 G6PD deficient cases whose pairs of controls had also been assessed for reaction. In the 30 cases of enzyme deficiency the total reaction score was 38 (average I.27), while in the 60 control cases the total reactions score was 59 with an average of almost exactly I. This second analysis confirms the findings from the larger group and suggests that G6PD deficient cases are more liable than others to suffer from reactions in leprosy.

\section{DISCUSSION}

G6PD deficiency is an inborn error of metabolism which is usually harmless, but which may give rise to in vivo haemolysis upon challenge with certain foods and drugs. Among the drugs incriminated have been DDS (GILles and TAYLOR I 96I) sulphoxone (DESFORGES et al i 959) and other substances of a similar chemical structure (SZEINBERG et al I958). It must be realised, however, that some authorities, e.g. GOODMAN and GILMAN ( 1955 ) believe 'haemolytic anaemia occurs to a varying degree in practically every patient taking sulphone drugs' although MARTINDALE ( I 958) believes it to be rare and PENGELLY ( I 963) suggests these statements 'could be compatible if GOODMAN and GILMAN had said "haemolysis" instead of haemolytic anaemia'. The emphasis in this study on controls has minimised variable factors which commonly occur and the findings can be used as an assessment of whether or not G6PD deficiency modifies the course of leprosy or its treatment.

It should be pointed out that many of the reports of dapsone-induced haemolysis concern patients who had not received sulphones for leprosy but for dermatitis herpetiformis. It is the habit of dermatologists to use sulphone for this disease in rather higher doses than is usually used for leprosy (often $200 \mathrm{mgm}$. per day) and so it is necessary to detail the routine anti-leprosy treatment that patients receive in Sungei Buloh Leprosarium. Treatment is usually by injection and starts with $0.5 \mathrm{ml}$. of injectable sulphones (200 mgm. per $\mathrm{ml}$.) and increases to twice weekly dosage of I $.5 \mathrm{ml}$. or $2 \mathrm{ml}$.: other patients receive DDS tablets and several in the past were given sulphetrone or other similar drugs in dosage arranged to produce a therapeutic effect equivalent to that of sulphone. All patients in the study were receiving 600 or $800 \mathrm{mgm}$. of sulphone per week which is about the same on average as the five cases on dapsone-induced haemolysis reported by PENGELLY. It is not thought likely, therefore, that 
C H A R T TWO

Assessment of Clinical Change

\begin{tabular}{|c|c|c|c|c|c|}
\hline \multicolumn{3}{|c|}{$G 6 P I)$ deficient cases } & \multicolumn{3}{|c|}{ Ciontrols } \\
\hline Score & Number & Percentage & Score & Number & Percentage \\
\hline+2 & $\mathrm{Nil}$ & 0.0 & +2 & Nil & 0.0 \\
\hline$+\mathbf{I}$ & 6 cases & $13 \cdot 3$ & $+\mathbf{I}$ & 8 cases & I I .9 \\
\hline 0 & 32 cases & 71.2 & 0 & 49 cases & $73 \cdot 2$ \\
\hline$-I$ & 6 cases & $13 \cdot 3$ & $-I$ & 9 cases & $13 \cdot 4$ \\
\hline-2 & I case & 2.2 & -2 & I case & 1.5 \\
\hline
\end{tabular}

T'otal change -2 in 45 cases

'lotal change -3 in 67 cases

CHART THREE

Reactions

$G$ G P D deficient cases

\begin{tabular}{|c|c|c|c|c|c|}
\hline Score & Number & Total Score & Score & Number & Tolal Score \\
\hline o & I 5 cases & o & o & 27 cases & o \\
\hline I & 9 cases & 9 & I & I 6 cases & I 6 \\
\hline 2 & 22 cases & 44 & 2 & 25 cases & $5^{0}$ \\
\hline & T'otal for 46 cases & 53 & \multicolumn{2}{|c|}{ Total for 68 cases } & 66 \\
\hline & Average & I. I 3 & \multicolumn{2}{|c|}{ Average } & 0.89 \\
\hline
\end{tabular}

proneness to haemolysis was missed because the dosage was too low to precipitate such a change and it is believed that this study shows very clearly that the overall course of leprosy treatment is not modified by G6PD deficiency although there is some evidence that during the period of treatment such patients are somewhat more likely to have one of the reactions associated with leprosy. There is also a suggestion of lower average haematocrit readings in the enzyme deficient patients but in all 47 cases who were found to be enzyme deficient it is interesting to note that there was no case of frank haemolytic anaemia nor were signs of haemolysis noticeable in the plasma of any of these cases.

We realised, of course, that this was a retrospective study and it is possible that some patients with G6PD deficiency had been admitted in 
the past and responded so markedly (cither in an advantageous or a disadvantageous manner) that they are no longer in the leprosarium. It secms logical therefore to suggest that a prospective study be carried out and that all patients on admission to the leprosarium be studied for enzyme deficiency and their response to treatment be watched $a b$ initio. It is hoped that this paper may stimulate other workers, as well as ourselves, to start such a study.

\section{SUMMAR Y}

In a survey of over I, ooo patients with leprosy, 47 cases $(4.4$ per cent) were found to have glucose-6-phosphate dehydrogenase deficiency. A controlled clinical study suggests that such a deficiency does not modify the overall response to therapy but may predispose to a greater tendency to leprosy reactions. All patients were receiving 600 to $800 \mathrm{mgm}$. of sulphone per weck and none had a frank hacmolytic anacmia.

\section{$\triangle$ CKNOWLEDGEMENTS}

This work could not have been carried out without the enthusiasm and assistance of the staff and patients of Sungei Buloh I.eprosarium to all of whom we offer our thanks.

During the study onc of us (J.C.) was supported by Public Health Service Grant GM - I I 329 - o3 from the ICMR'T Program, Office of International Research, National Institute of Health, US Public Health Service.

The Iseprosy Rescarch Unit at Sungei Buloh is supported by the Malaysian Ministry of Health and the British Medical Research Council.

\section{References}

beiguelman, в. (1962). Reaçāo Gustativa a Fenil-Tio-Carbamide (P'TC) e Lepra. Rev. Brasil Leprol. 30: I I I-I 24 .

beutler, e. (1 959). The Hemolytic Effect of Primaquine and Related Compounds: a Review Blood, 14: 103-139.

Brewer, G. J., TARlov, A. R., and Al.ving, A. s. (1962). 'The Methemoglobin Reduction Test for Primaquine-'Type-Sensitivity of Erythrocytes: $A$ simplified Procedure for detecting a specific Hypersensitivity for Drug Haemolysis. J. Amer. Med. Ass. 180: $386-388$.

DESFORges, J. F., THAYER, w. W., and DAwson, J. P. (I959). Haemolytic anemia induced by Sulfoxone therapy, with investigations into the mechanisms of its production. Amer. J. Med. 27: 132 .

goodman, L. s., and gillman, A. (1955). The Pharmacological Basis of Therapeutics. 2nd Ed. p. I, 253, Macmillan, New York.

Gilles, H. M., and TAYLOR, B. (i. ( 1961 ). The existence of the Glucose-6-phosphate-dehydrogenase deficiency trait in Nigeria and its Clinical Implications. Ann. trop. Med. Parasit. 55: 64-69. Gilles, H. m., Watson-williams, J., and taylor, B. G. (1960). Glucose-6-phosphate-Dehydrogenase Deficiency Trait in Nigeria. Nature, 185: 257-258.

hsuen, J., thomas e., and Jesudian, (. ( 1963 ). ABO Blood Groups and Leprosy. Leprosy Review 34: $143-147$.

marks, P. (1960). Glucose-6-phosphate dehydrogenase deficiency. Discussion in Proc. Ist Macy Conference on Genetics, p. 199.

martindale, w. (1958). The Extra Pharmacopoeia, 24th Ed, Vol. I, p. 537. Pharmaceutical Press, London.

motulsky, A. G. (1960). Population Genetics of Glucose-6-Phosphate-dehydrogenase deficiency of the Red Cell. Proceedings of the Conference on Genetics Polymorphisms and Geographic variations in Disease. 
PENGiel.ty, (.. D) R. (1963). 1)apsone-Induced Haemolysis. Brit. Med. J. ii: 662-664.

RIDI.EY, D. s., and JOPI.ING, w. H. (1962). $\Lambda$ Classification of Leprosy for Research Purposes. Leprosy Review 33: I 19-1 28 .

SPICKEтT, s. (i. (Ig62) a. Genetics and the Epidemiology of Leprosy, I, The Incidence of I eprosy. Leprosy Review, 33: 76-93.

SPICKETT, s. (. ( $\left(9^{62}\right)$ b. Genetics and the Epidemiology of Lcprosy II, 'The Form of Leprosy. Leprosy Review, 33: 173-181.

SZEINBERG, A., SHEBA Ch., and ADAm, A. (1958). Enzymatic abnormality in erythrocytes of a population sensitive to vicia faba or haemolytic anaemia due to drugs. Nature. 181 : 1, 256. 